\title{
Two superoxide dismutases from TnOtchr are involved in detoxification of reactive oxygen species induced by chromate
}

\author{
Rita Branco ${ }^{1,2}$ and Paula V. Morais ${ }^{1,2^{*}}$ (D)
}

\begin{abstract}
Background: Superoxide dismutases (SOD) have been reported as the most relevant bacterial enzymes involved in cells protection from reactive oxygen species (ROS). These toxic species are often the product of heavy metal stress.

Results: Two genes, chrC and chrF, from TnOtchr genetic determinant of strain Ochrobactrum tritici 5 bvl1 were cloned in Escherichia coli in order to overexpress the respective proteins. Both proteins were purified and characterized as superoxide dismutases. ChrC was confirmed as being a Fe-SOD, and the enzymatic activity of the ChrF, not inhibited by hydrogen peroxide or potassium cyanide, suggested its inclusion in the Mn-SOD family. This identification was supported by chemical quantification of total metal content in purified enzyme. Both enzymes showed a maximum activity between $\mathrm{pH}$ 7.2-7.5. ChrF retained nearly full activity over a broader range of $\mathrm{pH}$ and was slightly more thermostable than ChrC. The genes encoding these enzymes in strain 0 . tritici 5 bvl1 were inactivated, developing single and double mutants, to understand the contribution of these enzymes in detoxification mechanism of reactive oxygen species induced by chromate. During chromate stress, assays using fluorescent dyes indicated an increase of these toxic compounds in chrC, chrF and chrC/chrF mutant cells.
\end{abstract}

Conclusions: In spite of the multiple genes coding for putative superoxide dismutase enzymes detected in the genome of $\mathrm{O}$. tritici $5 \mathrm{bvl1}$, the $\mathrm{ChrC}$ and $\mathrm{ChrF}$ might help the strain to decrease the levels of reactive oxygen species in cells.

Keywords: Superoxide dismutases, Reactive oxygen species, Chromate stress, Mutant cells, Fluorescent dyes

\section{Background}

Oxygen present in the environment is potentially toxic to organisms because of the toxicity of reactive oxygen species (ROS) that are generated as by-products during the reduction of oxygen to water [1]. ROS such as superoxide radicals $\left(\mathrm{O}_{2}^{-}\right)$, hydrogen peroxide $\left(\mathrm{H}_{2} \mathrm{O}_{2}\right)$ and hydroxyl radical $(\mathrm{OH})$ enforce oxidative damage to the cells, for instance DNA strand breakage, protein inactivation, and membrane lipid peroxidation [2]. In order to deal with oxidative stress and to avoid the harmful effects of the ROS, most organisms have developed additional defense systems, which include superoxide dismutases (SODs) [3]. SODs are enzymes involved in

\footnotetext{
* Correspondence: pvmorais@ci.uc.pt

${ }^{1}$ CEMUC-Department of Mechanical Engineering, University of Coimbra, 3030-788 Coimbra, Portugal

2Department of Life Sciences, University of Coimbra, 3001-401 Coimbra, Portugal
}

C Biomed Central the detoxification of $\mathrm{O}_{2}^{-}$to $\mathrm{H}_{2} \mathrm{O}_{2}$ catalyzing the reaction: $2 \mathrm{O}_{2}^{-}+2 \mathrm{H}^{+} \rightarrow \mathrm{H}_{2} \mathrm{O}_{2}+\mathrm{O}_{2}$. Then, $\mathrm{H}_{2} \mathrm{O}_{2}$ is broken down to water by catalases and peroxidases [3, 4]. Therefore, SODs play a vital role in the primary defense line mechanisms against the oxidative stress.

SODs are metalloenzymes that can be classified into four groups according to their metal cofactor: the iron SOD (Fe-SOD), the manganese SOD (Mn-SOD), the copper zinc SOD (CuZn-SOD), the nickel SOD (NiSOD) [5]. There is also a particular group of SODs, the cambialistic SOD, that can function well either with iron or manganese at its active site [6,7]. The $\mathrm{Cu} / \mathrm{Zn}$-SODs are predominantly found in eukaryotes and in a few bacteria [8]. Most bacteria contain Fe- and/or Mn-SODs and some Ni-SODs have also been discovered in several Streptomyces species [9].

The expression of SODs in microorganisms is often related with response to heavy metal stress [10-12]. For 
instance, Rhodobacter capsulatus cells incubated with tellurite exhibited an increase in superoxide dismutase activity [13]. Proteome analysis of selenite response of Rhodobacter sphaeroides also showed enhanced synthesis of enzymes associated to oxidative stress [12].

It is well documented that ROS are products of $\mathrm{Cr}(\mathrm{VI})$ reduction and microorganisms in chromium contaminated environments should have developed defense systems against oxidative stress [14]. Bacterial cells when exposed to chromate activate several protective systems, including superoxide dismutase and catalase enzymes $[15,16]$. In our previous work, we have studied the genetic organization of a chromate resistance determinant (TnOtchr) of a highly resistant strain, Ochrobactrum tritici 5 bvl1 [17]. That work identified a set of $\mathrm{Cr}(\mathrm{VI})$ resistance genes: $c h r B$ encoding a chromate regulator [18], chrA encoding a chromate transporter and $\operatorname{chr} C$ and chrF, two SOD-like genes. ChrC of strain 5 bvl1 shows similarity to an identified Fe-SOD from Cupriavidus metallidurans [19]. In a previous work, ChrF and ChrC did not seem to play a crucial role in chromate resistance but, their expression in Escherichia coli increased resistance of cells to toxicity of reagents generating superoxide anions (17). However, little is known about specific features of $\mathrm{ChrC}$ and, up to date, there is no characterization of ChrF.

In the present work, these two putative SODs were characterized and their metal cofactors, sensitivity to inhibitors and molecular properties (molecular weight and protein oligomerization) were determined. Cloning and expression of the $c h r C$ and $c h r F$ genes in E. coli was performed in order to investigate the biochemical properties of the enzymes. Moreover, with the construction of $\operatorname{chrC}$ or/and chrF O. tritici mutants, the importance of these enzymes in the process of intracellular detoxification of ROS, generated by chromate, was demonstrated.

\section{Methods}

Bacterial strains, plasmids and growth conditions

Bacterial strains and plasmids used in this study are shown in Table 1. O. tritici 5 bvl1 strains were grown aerobically at $35{ }^{\circ} \mathrm{C}$ in Luria-Bertani (LB) medium

Table 1 Bacterial strains, plasmids and primers used in this work

\begin{tabular}{|c|c|c|}
\hline Strain or Plasmid & Relevant Characteristic(s) & Reference or Source \\
\hline \multicolumn{3}{|l|}{ Bacterial Strains } \\
\hline O. tritici 5 bvl1 & Type strain; $A m p^{r} ; C r(V I)^{r}$ & \\
\hline chrC mutant & Single mutant of $5 \mathrm{bv} l 1$; chrc mutated & This study \\
\hline chrF mutant & Single mutant of 5 bvl1; chrF mutated & This study \\
\hline chrC/chrF mutant & Double mutant of $5 \mathrm{bvl} 1$; chrC and chrF mutated & This study \\
\hline E. coli S17-1 & Conjugation donor strain & 22 \\
\hline E. coli 21(DE3) & $\mathrm{F}^{-}$ompT hsdS $\left(\mathrm{r}_{\mathrm{B}}{ }^{-}, \mathrm{m}_{\mathrm{B}}^{-}\right) \mathrm{gal} \mathrm{dcm}$ lacY1(DE3) & Novagen \\
\hline \multicolumn{3}{|l|}{ Plasmids } \\
\hline pJQ200SK & Suicide vector; $s a c B ; \mathrm{Gm}^{r}$ & ATCC \\
\hline pET30a & Kmr, expression plasmid & Novagen \\
\hline petChrC & pET30a for overproduction of ChrC with an C-terminal hexahistidine tag & This study \\
\hline petChrF & pET30a for overproduction of ChrF with an C-terminal hexahistidine tag & This study \\
\hline pchrc & pJQ200SK derivative carrying the upstream and downstream regions of chrC gene & This study \\
\hline \multicolumn{3}{|l|}{ Primers } \\
\hline NdechrCf & ATACATATGTCCTTCGACATTAAACCGC & This study \\
\hline SalchrCr & TCCGTCGACTGAGAGTCCTCCTGAGGGTTG & This study \\
\hline NdechrFf & CGACATATGAAATGGATTACCCGCGAAC & This study \\
\hline SalchrFr & CGAGTCGACCATCTTCGGCGGCCAGTTATG & This study \\
\hline chrCupf & GCTGGATCCTCTGGCTTGCTGCGGGTTGCC & This study \\
\hline chrCupr & GCTCTGCAGTCACAAGATCAAGGTCTTCAA & This study \\
\hline chrCdownf & GCTCTGCAGATGAAATGGATTACCCGCGAA & This study \\
\hline chrCdownr & CGACTCGAGTCACATCTTCGGCGGCCAGTT & This study \\
\hline chrFupf & GCTGGATCCAACGGCGTGTTGCCCGTAGGC & This study \\
\hline chrFupr & GCTCTGCAGTCATGAGAGTCCTCCTGAGGG & This study \\
\hline$c h r F^{\prime} f$ & GCTCTGCAGCCATGACGGTGAGCTTTGCAG & This study \\
\hline
\end{tabular}

Enzyme restriction site in primer sequences is shown in bold 
containing $10 \mathrm{~g} / \mathrm{L}$ tryptone, $5 \mathrm{~g} / \mathrm{L}$ yeast extract and $5 \mathrm{~g} / \mathrm{L}$ $\mathrm{NaCl}$. When required, this medium was supplemented with ampicillin $(100 \mu \mathrm{g} / \mathrm{mL})$, kanamycin $(50 \mu \mathrm{g} / \mathrm{mL})$ and sucrose (5\%). The strain E. coli BL21(DE3) was used for the expression of $c h r C$ and $c h r F$ and strain E. coli S17-1 was used as donor cells during the conjugation procedure.

\section{Expression and purification of SODs}

The full-length of $c h r C$ and $c h r F$ genes were amplified from O. tritici 5 bvl1 genomic DNA using the primer pairs NdechrCf/SalchrCr and NdechrFf/SalchrFr, respectively (Table 1) that corresponded to regions of their open-reading frames. The stop codon of each gene was removed from the reverse primer to allow the translation of a C-terminal His6-tag encoded by the expression vector pET30a (Novagen, San Diego, CA). The PCR products were digested with the respective restriction enzymes, electrophoresed and extracted from the gel. Then, DNA fragments were ligated into a pET30a vector, resulting in petChrC and petChrF plasmids, and transformed into competent E. coli BL21(DE3). The cloned genes were verified by DNA sequencing. Both proteins, ChrC-His6 and ChrF-His6 were overexpressed and purified using the same strategy. E. coli BL21(DE3) carrying the plasmids petChrC or petChrF were grown overnight at $37^{\circ} \mathrm{C}$ in $\mathrm{LB}$ containing kanamycin. The cultures were diluted 1:10 into $1 \mathrm{~L}$ of LB with kanamycin and incubated at $37{ }^{\circ} \mathrm{C}$ until 0.5 of optical density (OD) at $600 \mathrm{~nm}$. Then, isopropyl-D-thiogalactopyranoside (IPTG) was added to a final concentration of $0.5 \mathrm{mM}$, and incubation was continued overnight at $25{ }^{\circ} \mathrm{C}$. Bacterial cells were harvested, resuspended in $20 \mathrm{mM}$ sodium phosphate buffer at $\mathrm{pH} 7.4$ with $0.5 \mathrm{M} \mathrm{NaCl}$ and $20 \mathrm{mM}$ imidazole. A protease inhibitor cocktail (Roche, Mannheim, Germany), $10 \mu \mathrm{g} / \mathrm{mL}$ DNAse I and $5 \mathrm{mM}$ $\mathrm{MgCl}_{2}$ were added to the suspension. Cells were disrupted twice in a French-press cell followed by centrifugation $\left(15000 \times g, 4{ }^{\circ} \mathrm{C}, 40 \mathrm{~min}\right)$. The recombinant $\mathrm{ChrC}$ and $\mathrm{ChrF}$ proteins were purified in a prepacked $\mathrm{Ni}$ Sepharose high-performance column (His-Prep FF 16/ 10) equilibrated with $20 \mathrm{mM}$ sodium phosphate, $\mathrm{pH} 7.4$, $0.5 \mathrm{M} \mathrm{NaCl}$, and $20 \mathrm{mM}$ imidazole. Elution was carried out with $500 \mathrm{mM}$ imidazole and the eluted fractions containing the majority of $\mathrm{ChrC}$ or $\mathrm{ChrF}$ were concentrated by centrifugation in $10 \mathrm{kDa}$ cutoff centricons (Millipore, Bedford, MA), equilibrated with $50 \mathrm{mM}$ Tris, $\mathrm{pH}$ 7.4. The purity of fractions was assessed by electrophoresis on a $0.1 \%$ sodium dodecyl sulfate (SDS)- $12 \%$ polyacrylamide gel, followed by Coomassie blue staining. The purified ChrC-His6 and ChrF-His6 proteins were stored in buffer Tris $50 \mathrm{mM}$, pH 7.4 at $4{ }^{\circ} \mathrm{C}$. Protein concentrations were determined by using the Bradford assay (Bio-Rad, Hercules, CA) and bovine serum albumin (BSA) (Sigma, St. Louis, MO) as the protein standard.

\section{SOD activity staining}

SOD activity was visualized on a non-denaturing polyacrylamide gel as previously described [20]. Proteins $(10 \mu \mathrm{g})$ were subjected to $10 \%$ native-PAGE. Gels were incubated with $0.1 \%$ Nitroblue tetrazolium (NBT) solution in dark with shaking for $15 \mathrm{~min}$ at room temperature and then incubated with Riboflavin solution (28 $\mu \mathrm{M}$ riboflavin and $28 \mathrm{mM}$ TEMED in $0.1 \mathrm{M}$ potassium phosphate buffer, $\mathrm{pH}$ 7.0) in dark with shaking for $15 \mathrm{~min}$ at room temperature. Gels were illuminated with a white-light box at room temperature and the SOD activity area appeared as a clear zone on a blue-violet background. The effect of several compounds on enzymes activity was tested to differentiate both SODs. The enzyme $(10 \mu \mathrm{g})$ was mixed with potassium cyanide (KCN, $10 \mathrm{mM})$, sodium azide $\left(\mathrm{NaN}_{3}, 10 \mathrm{mM}\right)$ or hydrogen peroxide $\left(\mathrm{H}_{2} \mathrm{O}_{2}, 10 \mathrm{mM}\right)$ and incubated at $30{ }^{\circ} \mathrm{C}$ for $1 \mathrm{~h}$. After incubation, the SOD activity was assayed in native gels as describe above.

\section{SOD assay in solution}

SOD activity was determined using the photochemical microplate assay method [21] and measuring enzyme ability to inhibit the photochemical reduction of NBT. The reactions were performed in $50 \mathrm{mM}$ phosphate buffer $\mathrm{pH} 7.5$ or $50 \mathrm{mM}$ Tris- $\mathrm{HCl}$ buffer $\mathrm{pH}$ 7.2, for ChrC or ChrF assays, respectively. Besides the buffer solutions, the reaction mixture was composed by $13 \mathrm{mM}$ methionine, $75 \mu \mathrm{M}$ NBT, $2 \mu \mathrm{M}$ riboflavin, $0.1 \mathrm{mM}$ EDTA, and $2 \mu \mathrm{g}$ of enzyme. Riboflavin was added last into the reaction mixture. The microplate was placed $30 \mathrm{~cm}$ below two $40-\mathrm{W}$ lamps and the reaction was run for $15 \mathrm{~min}$. Absorbance was read at $560 \mathrm{~nm}$ using a spectrophotometer (Infinite M200, Fisher). Reaction mixture without enzyme was also performed as a control, which developed the maximum color.

In cellular extracts, the total SOD activities were defined as $\mathrm{U} / \mathrm{mg}$ protein and one enzyme unit corresponds to $50 \%$ inhibition of the reaction.

\section{Optimal $\mathrm{pH}$, thermal and $\mathrm{pH}$ stability assays}

To determine the optimal $\mathrm{pH}$ for SOD activity, the purified enzymes were assayed in $50 \mathrm{mM}$ of several buffers instead of the assay solution described above. The buffer solutions used were $50 \mathrm{mM}$ citrate buffer ( $\mathrm{pH} 4-6$ ), potassium phosphate buffer ( $\mathrm{pH}$ 6-8), Tris- $\mathrm{HCl}$ Buffer ( $\mathrm{pH} 7.2-10)$ and carbonate-bicarbonate buffer $(\mathrm{pH} 11)$. After 15-min incubation at $30 \mathrm{~cm}$ below two 40-W lamps, SODs activities were measured.

The $\mathrm{pH}$ stability of $\mathrm{ChrC}$ and $\mathrm{ChrF}$ enzymes were tested by incubation in solutions ranging from $\mathrm{pH} 4$ to 
11 for $3 \mathrm{~h}$. The thermal stability of $\mathrm{ChrC}$ and $\mathrm{ChrF}$ was determined by incubating the purified enzymes at temperatures from 22 to $65{ }^{\circ} \mathrm{C}$ for $3 \mathrm{~h}$. After incubation time, the remaining SOD activity was determined, as indicated above under standard conditions and calculated as the percentage of the maximum SOD activity.

\section{Metal analyses}

Metal present in the purified $\mathrm{ChrC}$ and $\mathrm{ChrF}$ proteins were analyzed using Inductively Coupled Plasma Mass Spectrometry (ICP-MS) in an ICP-MS Thermo X Series. First, protein was frozen at $-20{ }^{\circ} \mathrm{C}$ for $10 \mathrm{~min}$, heated at $50{ }^{\circ} \mathrm{C}$ for 60 to $120 \mathrm{~min}$ and then centrifuged at $4000 \mathrm{rpm}$ for $30 \mathrm{~min}$, at $4{ }^{\circ} \mathrm{C}$. The supernatants were collected and submitted to analyses of iron, manganese, nickel, zinc and copper.

\section{Evaluation of the oligomeric state of $\mathrm{ChrC}$ and $\mathrm{ChrF}$}

To determine whether $\mathrm{ChrC}$ and $\mathrm{ChrF}$ are in oligomeric form, chemical crosslinking assays were performed using glutaraldehyde. Reaction mixtures containing $10 \mu \mathrm{g}$ of purified enzymes in crosslinking buffer $(20 \mathrm{mM} \mathrm{NaCl}$, $10 \mathrm{mM} \mathrm{KCl}, 2 \mathrm{mM}$ DTT in $20 \mathrm{mM}$ Hepes, pH 7.5) were incubated with glutaraldehyde to a final concentration of $0.1 \%$, and the reaction mixture was incubated for 5,15 and $30 \mathrm{~min}$ at $30{ }^{\circ} \mathrm{C}$. Crosslinking was terminated by adding SDS-PAGE sample buffer, heating at $95{ }^{\circ} \mathrm{C}$ for $5 \mathrm{~min}$, and the samples analyzed by $12 \%$ SDS-PAGE.

The purified ChrC and ChrF were subjected to gel filtration using a Superdex 200 10/300 GL packed column (GE Healthcare). The elution volume of standard proteins of alcohol dehydrogenase $(150 \mathrm{kDa})$, bovine serum albumin (BSA) (66 kDa), carbonic anhydrase (29 kDa), and ribonuclease $(13.7 \mathrm{kDa})$ were first detected, followed by gel filtration of the recombinant enzymes under the same conditions. The molecular mass curve of the standard proteins was thus constructed and the molecular mass of ChrC and ChrF was calculated.

\section{Construction of Ochrobactrum tritici 5bvl1 mutants}

Single $c h r C$ mutant was constructed by deletion of the $c h r C$ gene from chr operon of native strain. Briefly, the upstream gene portion of $c h r C$ gene, of around $400 \mathrm{bp}$, amplified by specific primers, chrCupf and chrCupr and the downstream gene portion of $\operatorname{chr} C$ gene, of about $450 \mathrm{bp}$, amplified using the specific primers, chrCdownf and chrCdownr were digested with the pair of enzymes respectively. These fragments were cloned into pJQ200sk vector at the BamHI/PstI and PstI/XhoI restriction sites resulting in $\mathrm{p} c h r C$ plasmid. This plasmid was transformed into E. coli S17-1 and transferred to the recipient strain $O$. tritici 5 bvl1 by biparental conjugation using the filter mating method [22]. Double-crossover transconjugants were selected on LB plates with ampicillin and sucrose. Positive mutants (chrC mutant) were confirmed by PCR using the specific primers to amplify the $\operatorname{chr} C$ gene. Single mutant, $c h r F$ mutant, was obtained by removing part of the $c h r F$ gene of strain 5bvl1. Succinctly, a fragment of about 300 bp corresponding to the upstream gene portion of $c h r F$ gene was amplified by specific primers, chrFupf and chrFupr. The terminal chrF gene portion of 280 bp was amplified using the specific primers chrF'f and SalchrFr. As above, the PCR products were digested with the pair of enzymes respectively, cloned into pJQ200sk vector, transformed into E. coli S17-1 and transferred to the strain 5bvl1. The transconjugants were also selected on LB plates with ampicillin and sucrose. Positive mutants (chrF mutant) were confirmed by PCR using the specific primers to amplify the total $c h r F$ gene. Double mutant, $c h r C / c h r F$ mutant, was constructed using the previous strategies to delete the $\operatorname{chr} C$ gene and remove partially the $c h r F$ gene. Thus, the suicide plasmid pchrC transformed in E. coli S17-1 was used to conjugate with the recipient strain $c h r F$ mutant. Transconjugants were selected on LB plates with ampicillin and sucrose and positive clones (chrC/chrF mutant) were confirmed by PCR.

\section{Determination of intracellular oxidation levels}

The oxidant-sensitive probe $2^{\prime}, 7^{\prime}$-dichlorodihydrofluorescein diacetate $\left(\mathrm{H}_{2} \mathrm{DCFDA}\right.$, Sigma Aldrich, Germany) [23] was used to determine the intracellular levels of ROS in O. tritici 5bvl1 wild type and mutant cells untreated and treated with chromate. Cells were grown overnight aerobically in LB medium or in chromate $(0,5$; 1; $2 \mathrm{mM}$ )-amended LB medium. Then, cells were diluted at OD 0.5 and washed twice with Phosphate Buffer Salt (PBS) ( $\mathrm{pH} \mathrm{7.0).} \mathrm{Cells} \mathrm{were} \mathrm{incubated} \mathrm{for} 30 \mathrm{~min}$ in the same buffer containing $25 \mu \mathrm{M} \mathrm{H}_{2}$ DCFDA dissolved in dimethyl sulfoxide. After three washing steps, the cells were suspended in the same buffer and the fluorescence intensity was immediately measured at each $1 \mathrm{~h}$ interval, over a $3 \mathrm{~h}$ period, using fluorescence microplate reader (Infinite M200, Fisher) (excitation, $495 \mathrm{~nm}$; emission, $517 \mathrm{~nm}$ ). All the values were normalized by optical density measured at $600 \mathrm{~nm}$.

\section{Results}

\section{Expression and molecular properties of enzymes}

The genes chrC and chrF of TnOtchr of O. tritici 5 bvl1 code for two putative SODs with different subcellular localization predicted by the informatics program PSORTb version 3.0.2 [24]. While ChrC was identified as a putative periplasmic protein (score 9.44), ChrF was identified as a cytoplasmic protein (score 8.96). In this work, the genes $c h r C$ and $c h r F$ of $O$. tritici 5 bvll were highly expressed in $E$. coli BL21(DE3). The heterologous 
proteins were purified using Ni-NTA affinity chromatography. The monomeric molecular mass of the recombinant $\mathrm{ChrC}$ and $\mathrm{ChrF}$ was found to be approximately $25 \mathrm{kDa}$ and $19 \mathrm{kDa}$, respectively (Fig. 1). These masses corresponded to the sum of each predicted molecular mass of the proteins $(\sim 22 \mathrm{kDa}$ and $\sim 17 \mathrm{kDa})$ and the (His)6 tag $(\sim 2.6 \mathrm{kDa})$.

To determine the oligomeric status of both proteins, chemical crosslinking experiments were performed on purified recombinant enzymes. Analysis of the reaction mixtures that contained purified $\mathrm{ChrC}$-His6 and ChrFHis6 with glutaraldehyde resulted in shifting position bands on SDS-PAGE. Increasing incubation time of $\mathrm{ChrC}$ with glutaraldehyde resulted in the appearance of a strong band on the gel slightly above of $100 \mathrm{kDa}$, corresponding to a tetramer (Fig. 2a). Incubation of ChrF with glutaraldehyde over time caused a shifting of the monomeric to dimeric status of protein, revealed by appearance of a strong band at position of approximately of $35 \mathrm{kDa}$ on gel (Fig. 2b).

The molecular mass of the recombinant $\mathrm{ChrC}$ and $\mathrm{ChrF}$ proteins was also analyzed by size exclusion chromatography and determined as $96.2 \mathrm{kDa}$ and $39.4 \mathrm{kDa}$, respectively, (Fig. 3). These results suggest that $\mathrm{ChrC}$ is a tetrameric protein comprising four subunits of $24.6 \mathrm{kDa}$ and $\mathrm{ChrF}$ is a dimer comprising two subunits of $19.6 \mathrm{kDa}$. These molecular masses were in agreement with the results obtained from the chemical crosslinking assays.

\section{Identification of the metal cofactor}

The activity of ChrC and ChrF as SODs were evaluated on non-denaturing polyacrylamide gels. The purified recombinant proteins showed achromatic zones in activity staining gels revealing that both enzymes exhibit activity of SOD (Fig. 4). Additionally, compounds, such as $\mathrm{H}_{2} \mathrm{O}_{2}, \mathrm{NaN}_{3}$ and $\mathrm{KCN}$ were tested to assess their inhibitory effect on the activities of both enzymes. Figure 4a shows no white band when $\mathrm{ChrC}$ was incubated with $\mathrm{H}_{2} \mathrm{O}_{2}$, indicating that ChrC was inhibited by $\mathrm{H}_{2} \mathrm{O}_{2}$ and not by $\mathrm{KCN}$, an expected characteristic of the Fe-SODs. On the other hand, there was no difference between the bands obtained on activity gels when $\mathrm{ChrF}$ was treated with the inhibitors and the control (Fig. 4b). These results indicate that ChrF activity was not inhibited by cyanide or $\mathrm{H}_{2} \mathrm{O}_{2}$, a common characteristic of Mn-SODs. Both enzymes were not inhibited by azide in the tested concentration.

The metal cofactors of both proteins were also confirmed through quantification of the metal content by ICP-MS. These analyses showed that iron was the most abundant metal in the purified $\mathrm{ChrC}$ protein $(1.4 \mathrm{~mol}$ $\mathrm{Fe} / \mathrm{mol}$ enzyme) and manganese, with $1.0 \mathrm{molMn} / \mathrm{mol}$ enzyme, was the major element present in the ChrF protein sample (Table 2). Therefore, the results obtained by inhibition tests and metal analyses are coherent indicating that $\mathrm{ChrC}$ and $\mathrm{ChrF}$ are a Fe-SOD and Mn-SOD, respectively.

\section{Effect of metals on SODs activity}

The assays of $\mathrm{ChrC}$ and $\mathrm{ChrF}$ with several metals showed distinct effects of metals on the SODs activity revealed by native staining gels. The protein $\mathrm{ChrC}$ was only inhibited by $\mathrm{Cr}(\mathrm{III})$ (Fig. 5a). On the other hand,
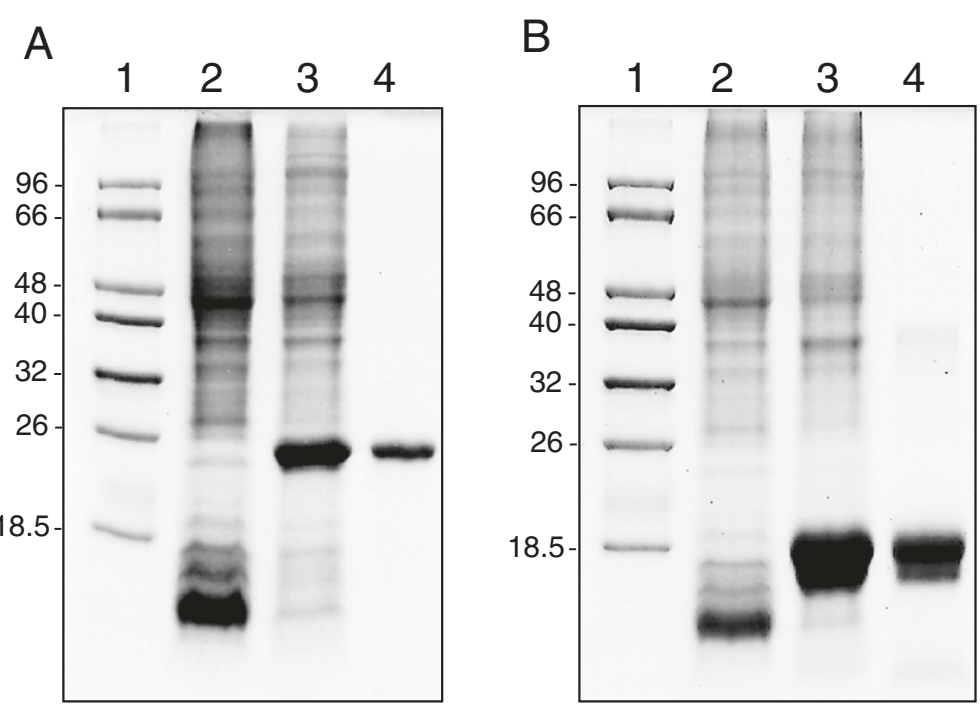

Fig. 1 ChrC (a) and ChrF (b) were overexpressed with carboxy-terminal 6-histidine tags in E. coli BL21 (DE3). Lane 1, DNA ladder; lane 2, whole-cell extract from uninduced cells containing pET30a expressing the proteins; lane 2, whole-cell extract from induced cells containing pET30a expressing the proteins; lane 3, purified ChrC-His6 (a) and ChrF-His6 (b) by Ni2+ nitrilotriacetic acid affinity chromatography 
A

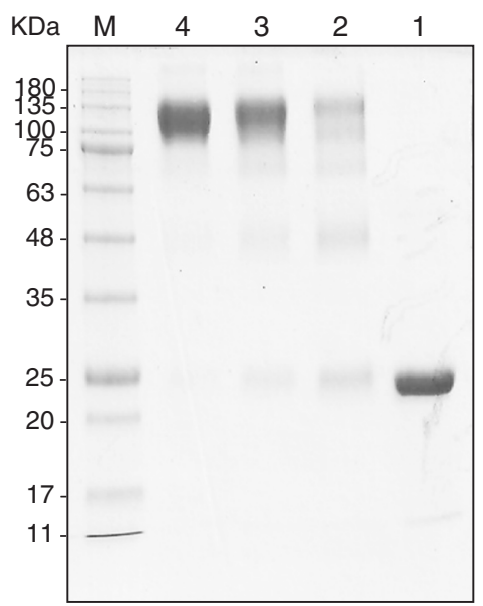

\section{$\mathrm{B}$}

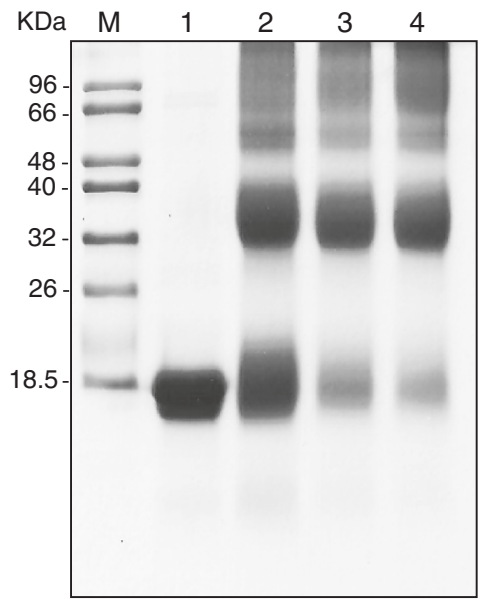

Fig. 2 Chemical crosslinking assays. SDS-PAGE of purified ChrC (a) and ChrF (b) in glutaraldehyde crosslinking assays. Lane 1, protein without glutaraldehyde; lane 2, protein + glutaraldehyde (5 min); lane 3, protein + glutaraldehyde (15 min); lane 4, protein + glutaraldehyde (30 min)

ChrF was completely inhibited by $\mathrm{Cr}(\mathrm{III})$, Fe(II) and $\mathrm{Cd}(\mathrm{II})$ and was partially inhibited by $\mathrm{Cu}(\mathrm{II})$ (Fig. 5 b).

\section{Optimum $\mathrm{pH}$, stability to $\mathrm{pH}$ and temperature}

The effect of $\mathrm{pH}$ on the activity of purified SOD enzymes was determined using buffers at various $\mathrm{pH}$ values. The ChrC enzyme was highly active over a broad range of $\mathrm{pHs}$ tested $(6.0$ - 11.0) and showed maximum activity in phosphate buffer $\mathrm{pH} 7.5$. ChrF was optimally active at Tris- $\mathrm{HCl} \mathrm{pH} 7.2$ and showed activity over a narrower range of pHs (6.0 - 9.0) (Fig. 6a).

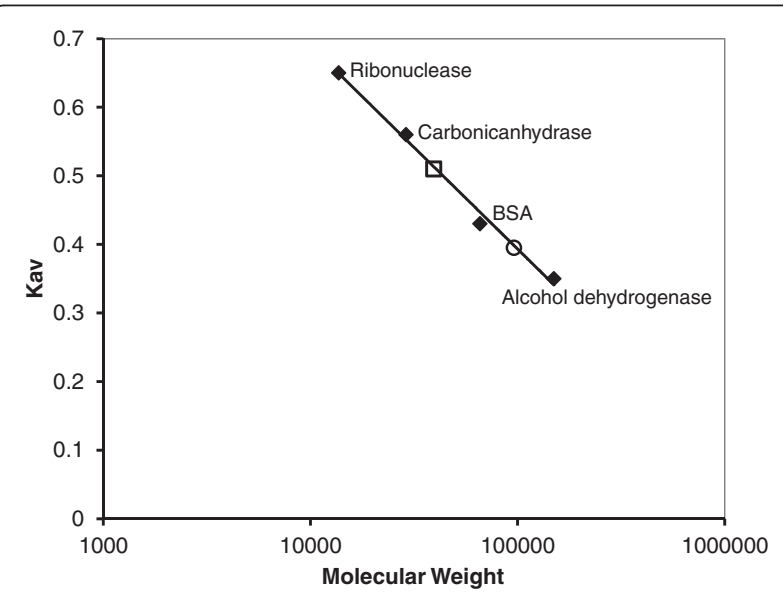

Fig. 3 Determination of the molecular mass of ChrC and ChrF by gel filtration. Chromatography was performed on Superdex 200 10/ $300 \mathrm{GL}$ packed column at a flow rate of $0.5 \mathrm{~mL} / \mathrm{min}$ with $50 \mathrm{mM}$ Tris- $\mathrm{HCl}, 0.15 \mathrm{M} \mathrm{NaCl}, \mathrm{pH} 7.4 . \mathrm{K}_{\mathrm{av}}$ values were calculated using the equation: $K_{a v}=\left(V e-V_{0}\right) /(V c-V o)$, where $V_{0}$ is column void volume, Ve is elution volume, and $V c$ is geometric column volume. The studied proteins are represented by open symbols: $\operatorname{ChrC~(o);~ChrF~(~} \square$ )
For the pH stability test, enzymes were incubated for $3 \mathrm{~h}$ at various $\mathrm{pHs}$ and then assayed at the optimum pHs. The ChrF retained nearly full activity over a broad range of $\mathrm{pH}(4.0-11.0)$ and the $\mathrm{ChrC}$ held more than $50 \%$ of total activity at $\mathrm{pH}$ between $5.0-10.0$ but its stability was seriously affected at low pHs (Fig. 6b).

Both enzymes showed high thermal stability at temperatures lower than $45{ }^{\circ} \mathrm{C}$, retaining more than $80 \%$ of their activities (Fig. 6c) and both were unstable at temperatures above $65{ }^{\circ} \mathrm{C}$. Moreover, over all tested temperatures, $\mathrm{ChrF}$ was slightly more stable than $\mathrm{ChrC}$.

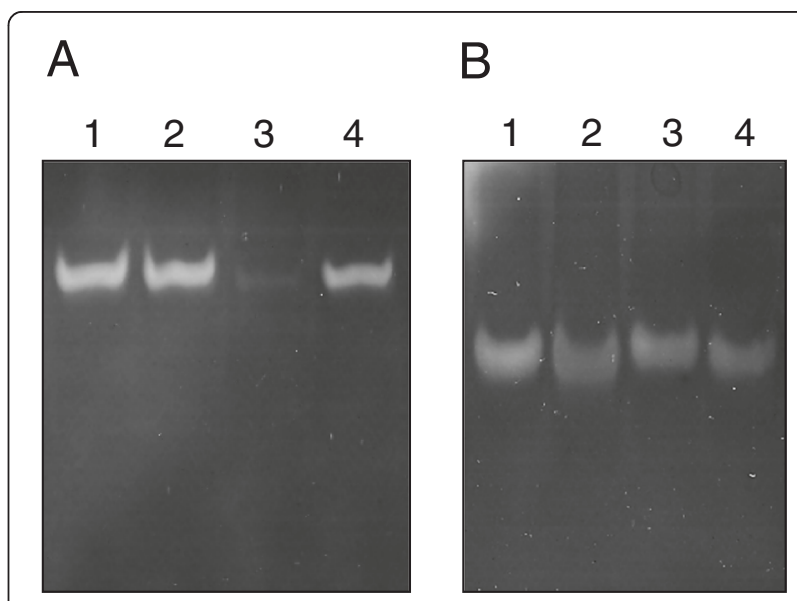

Fig. 4 Activity staining of the purified $\mathrm{ChrC}$ (a) or ChrF (b) proteins electrophoresed on $10 \%$ nondenatured polyacrylamide gel. Lane 1, enzymatic reaction in absence of inhibitor; lane 2, enzyme incubated with $10 \mathrm{mM} \mathrm{KCN}$; lane 3, enzyme incubated with $10 \mathrm{mM} \mathrm{H}_{2} \mathrm{O}_{2}$; lane 4, enzyme incubated with $5 \mathrm{mM} \mathrm{NaN}_{3}$ 
Table 2 Metal contents of ChrC and ChrF

\begin{tabular}{llc}
\hline Metal & $\mathrm{mol} \mathrm{metal} / \mathrm{mol}$ of ChrC & $\mathrm{mol}$ metal $/ \mathrm{mol}$ of $\mathrm{ChrF}$ \\
\hline $\mathrm{Cu}$ & 0.003 & 0.013 \\
$\mathrm{Fe}$ & 1.4 & 0.073 \\
$\mathrm{Mn}$ & 0.32 & 1.0 \\
$\mathrm{Ni}$ & 0.043 & 0.028 \\
$\mathrm{Zn}$ & 0.07 & 0.11 \\
\hline
\end{tabular}

\section{Effect of chromate on the generation of ROS in O. tritici 5 bvl1}

To investigate whether ROS is involved in the toxicity of chromate, the intracellular ROS levels of control and chromate-exposed cultures were compared. When the results obtained immediately after the $30 \mathrm{~min}$ of incubation of cells with the fluorescent probe were compared, we observed that wild cells showed only a slight increase of fluorescence level at concentrations of chromate upper than $1 \mathrm{mM}$. On the other hand, the mutated cells, mostly the $c h r C$ and $c h r C / c h r F$ mutants, showed a dramatic high level of fluorescence when exposed to chromate concentration over $0.5 \mathrm{mM}$ (Fig. 7a). Interestingly, the fluorescence signal was not proportional to chromate concentration, implying that $0.5 \mathrm{mM}$ of chromate was enough to induce high ROS generation in mutated cells. Figure $7 \mathrm{~b}$ shows the fluorescence measured over time after the probe removal. It is noticeable that, in the case of cells not exposed to chromate, fluorescence did not increase. However, all cells exposed to $1 \mathrm{mM}$ of chromate showed continuously increase of fluorescence level. Moreover, the intensification of fluorescence signal was stronger for $c h r C$ and $c h r C / c h r F$ mutants.

Measurement of total superoxide dismutase activities upon chromate exposure was also analyzed for wild-type strain and mutants. The mean values of SOD activity of the wild type was higher $(780 \pm 193 \mathrm{U} / \mathrm{mg}$ protein) than mutants $(622 \pm 189 \mathrm{U} / \mathrm{mg}$ protein of $c h r C, 622 \pm 191 \mathrm{U} /$ $\mathrm{mg}$ protein of $\mathrm{chrF}$ and $600 \pm 210 \mathrm{U} / \mathrm{mg}$ protein of $\mathrm{chrC} /$
chrF). Statistical analysis of all data (8 independent assays) performed by two-way ANOVA with Tukey's multiple comparison post-test showed significant difference among mutants and control cells $(P<0.05)$.

\section{Discussion}

Bacterial chromate resistance is often associated to the presence of a chr genetic determinant carrying, at least, a chrA gene coding for a well-known chromate efflux pump [14]. However, in many strains, the chr operon is also composed by others genes coding for proteins not sufficiently studied or characterized. In this work, ChrC and $\mathrm{ChrF}$ were characterized and their features compared since the respective genes, $\operatorname{chr} C$ and $\operatorname{chrF}$, belong to the chromate inducible operon TnOtchr [17]. The results from this study identified $\mathrm{ChrC}$ and $\mathrm{ChrF}$ as two different SODs, a Fe-SOD and Mn-SOD respectively. In fact, the strong sequence homology between ChrCs of $O$. tritici and C. metallidurans has already suggested that enzyme was a Fe-SOD [19]. This enzyme exhibited typical FeSOD-like characteristics in sensitivity to inhibitors i.e. it was inactivated by $\mathrm{H}_{2} \mathrm{O}_{2}[25,26]$. On the other hand, ChrF was seen for the first time as an enzyme with SOD activity. Its insensitivity to the tested inhibitors, $\mathrm{H}_{2} \mathrm{O}_{2} ; \mathrm{KCN}, \mathrm{NaN}_{3}$, suggested that ChrF in O. tritici 5 bvl1 may be a member of the Mn-SODs. This was supported by the presence of $1.0 \mathrm{~mol}$ of $\mathrm{Mn}$ per mole of purified enzyme. In general, Fe-SODs are the most well characterized SODs but more recently, the biological functions of Mn-SOD have deserved a special attention by researchers. This type of enzyme is reported to be involved in different processes such as senescence, cell impairment and carcinogenesis [27, 28].

Besides the different sensitivity of both SODs to the inhibitors, these enzymes also exhibited others distinct features. In $\mathrm{pH}$ stability test, the enzyme ChrF was remarkably stable, retaining nearly full activity between $\mathrm{pH}$ 4-11. The different oligomerization between these

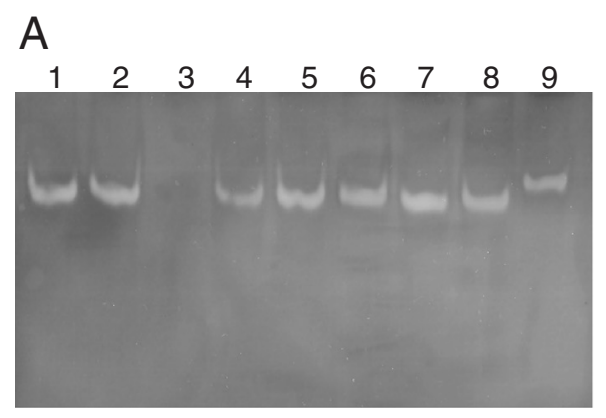

$\mathrm{B}$

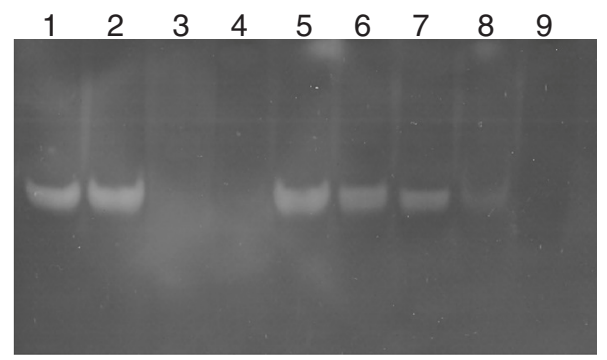

Fig. 5 Effect of several metal ions on SOD activity of purified ChrC (a) or ChrF (b) enzymes. Lane1, enzymatic reaction in absence of any tested compound; lane 2, enzyme incubated with chromate, lane 3, enzyme incubated with $\mathrm{Cr}(\mathrm{III)}$; lane 4, enzyme incubated with Fe(II); lane 5, enzyme incubated with $\mathrm{Mn}(\mathrm{II})$; lane 6, enzyme incubated with $\mathrm{Ni}(\mathrm{II})$; lane 7, enzyme incubated with Zn(II); lane 8, enzyme incubated with $\mathrm{Cd}(\mathrm{II})$; lane 9, enzyme incubated with $\mathrm{Cu}(\mathrm{II})$ 


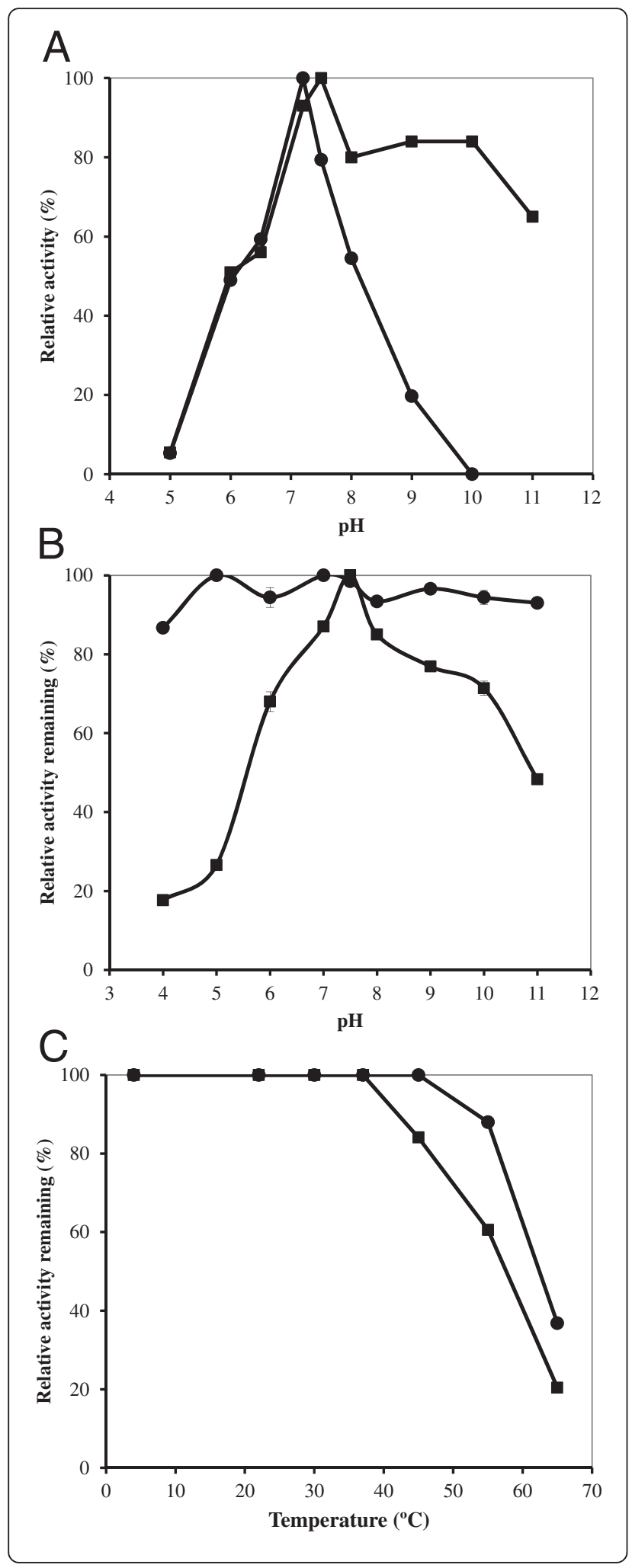

Fig. 6 Effect of pH on SODs activity (a) and stability of SODs to pH (b) and temperature (c). a The purified enzymes were assayed at different $\mathrm{pHs}$. $\mathbf{b} \mathrm{pH}$ stability was determined by incubating the proteins in different pHs for $2 \mathrm{~h}$ prior to SOD assays at their optimum $\mathrm{pH}$. $\mathbf{b}$ Thermal stability was determined after incubation of the purified proteins for $2 \mathrm{~h}$ at the indicated temperatures. ChrC assays (घ); ChrF assays $(\bullet)$

two SODs (ChrC - tetramer; ChrF - dimer) could possibly explain the different $\mathrm{pH}$ stability. The susceptibility of $\mathrm{ChrC}$, mainly to acidic pHs, may be due to the reported effect of acidic conditions in the dissociation of the functional tetramers into monomers, disturbing the enzyme activity [21]. Although, both enzymes were thermostable up to $45{ }^{\circ} \mathrm{C}$ retaining more than $80 \%$ of SOD activity, ChrF showed more thermal stability than ChrC. In fact, literature refers that most of the SODs are very stable in the range of temperatures from 25 to $45{ }^{\circ} \mathrm{C}$, but SODs from thermophiles revealed higher stability [29-31]. The thermostability is often associated to the high number of charged residues, hydrophobic residues, increased number of ion-pairs, and increased buried surface [32, 33]. The number of charged residues (lysine, arginine, glutamic acid and aspartic acid, total $23.1 \%$ ) of ChrF is considerably higher than ChrC (total $17 \%$ ). This may explain in some ways the higher thermostability of ChrF.

It is well recognized that the toxic effect of chromate involves predominantly oxidative stress generated by the intracellular reduction of $\mathrm{Cr}(\mathrm{VI})$ to the highly reactive radical $\mathrm{Cr}(\mathrm{V})$ that through redox reactions ends as $\mathrm{Cr}(\mathrm{III})$ and results in ROS production $[34,35]$. These species are directly implicated in damage of cellular components such as DNA and proteins $[14,36]$. To assess the cellular oxidative stress generated by chromate in $\mathrm{O}$. tritici cells and to evaluate a possible contribute of the ChrC or ChrF in ROS detoxification, the intracellular concentration of oxygen reactive species was measured using the specific probe $\mathrm{H}_{2}$ DCFDA. Chromate treatment increased cytoplasmic ROS and this increase was clearly more visible in the SOD mutants. Previous studies with E. coli cells not challenged with chromate have already shown little degree of green fluorescence comparatively with the fluorescence signal from chromatechallenged cells [15]. In our results, an increase in the cytoplasmic ROS concentration also suggest that in $O$. tritici 5 bvl1 the chromate induced more stress in $\mathrm{ChrC}$ and $\mathrm{ChrF}$ deficient cells.. Differences in SOD activities between the wild type and the mutants were also observed together with differences between cytoplasmic ROS levels. Comparing the ROS levels from both single mutants, we conclude that $\operatorname{chrC}$ mutation exerts a more drastic effect in cells even when SODs activities of both mutants were similar, which could 

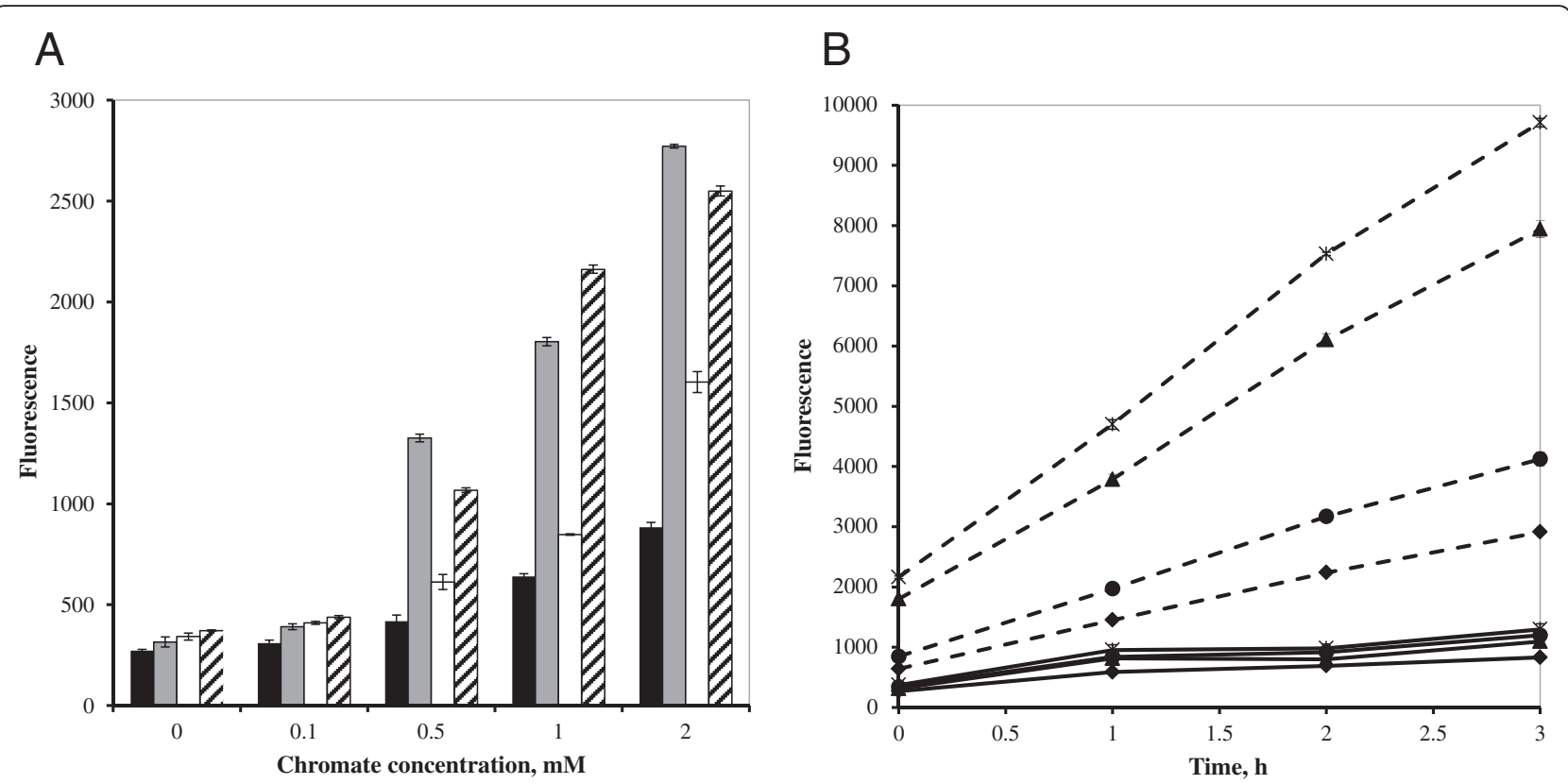

Fig. 7 Generation of intracellular ROS by chromate. a Cytoplasmic ROS content was evaluated measuring the $\mathrm{H}_{2}$ DCFDA probe activation in cells of, wild strain O. tritici 5 bvl1 (black bar); chrC mutant (grey bar); chrF mutant (white bar) and chrC/chrF mutant (dashed bar), treated with indicated concentrations of chromate. $\mathbf{b}$ Comparative fluorescence signals of cells untreated (solid line) or treated (dashed line) with $1 \mathrm{mM}$ chromate over time for wild strain O. tritici 5 bvl1 ( $)$; $\operatorname{chrC}$ mutant $(\mathbf{\Delta})$; $\operatorname{chrF}$ mutant $(\bullet)$ and $\operatorname{chrC/ChrF~mutant~}(\mathrm{x})$

be explained by the sensitivity of the techniques used. The differences observed in the ROS levels of the mutants could be related to the different predicted location of their SODs in cells. Cellular enzymes sharing similar functions, when subjected to stress conditions, could exhibit distinct performances. Studies of bacterial transcription analysis have shown that several genes known to be involved in response to oxidative stress were up-regulated under either chromate or dichromate stress. The up-regulation of Sod was observed for $\mathrm{Cr}(\mathrm{VI})$-stressed E. coli [15], Pseudomonas putida [34] and Caulobacter crescentus [16] but not for Shewanella oneidensis MR-1 [37]. Moreover, C. crescentus showed differential expression of their SOD encoding genes under chromium stress. Its $\operatorname{SodA}$ showed an induction from 9-fold to 14-fold and the other two superoxide dismutase genes showed up to 2 -fold induction [16].

The exploration of draft genome from strain O. tritici 5 bvl1 showed two additional superoxide dismutase related genes which should code for functional SODs responsible for the general bacterial detoxification processes (unpublished results). These two identified SODs showed high homology between each other and they shared higher homology with $\mathrm{ChrC}$ than with $\mathrm{ChrF}$. The presence of several SODs is a characteristic often present in bacteria. For instance in Agrobacterium tumefaciens, each SOD displays different expression pattern and cellular location [38].

\section{Conclusions}

In summary, the chromate resistant strain $O$. tritici 5 bvll carries a transposable element (TnOtchr) that includes determinants coding for a chromate efflux pump and two distinct SOD enzymes. In addition to other putative SODs detected from bacterial genome analysis, the new characterized $\mathrm{Fe}-\mathrm{SOD}(\mathrm{ChrC})$ and $\mathrm{Mn}$-SOD $(\mathrm{ChrF})$ ensure that superoxide anions are kept at physiologically safe levels allowing the growth of $O$. tritici. Moreover, the presence of $\mathrm{ChrC}$ and $\mathrm{ChrF}$ seems to be relevant to avoid ROS accumulation in chromate stressed cells.

\section{Competing interests}

The authors declare that they have no competing interests.

\section{Authors' contributions}

$\mathrm{RB}$ conceived and designed all the experiments, performed the experiments and analyzed the data. PVM analyzed the data and contributed with reagents/materials/analysis tools. Both authors wrote the paper, read and approved the final manuscript.

\section{Acknowledgments}

This work was supported by the project PTDC/BIA-MIC/114958/2009 from Fundação para a Ciência e Tecnologia (FCT). Rita Branco was funded by a grant SFRH/BPD/48330/2008.

Received: 16 September 2015 Accepted: 29 February 2016

Published online: 05 March 2016

\section{References}

1. Imlay JA. The molecular mechanisms and physiological consequences of oxidative stress: lessons from a model bacterium. Nature Rev Microbiol. 2013;11:443-54. 
2. Krieg NR, Hoffman PS. Microaerophily and oxygen toxicity. Ann Rev Microbiol. 1986;40:107-30.

3. Fridovich I. Superoxide radical and superoxide dismutases. Ann Rev Biochem. 1995;64:97-112.

4. Halliwell B, Gutteridge JMC. Free radicals in biology and medicine. 3rd ed. New York: Oxford University Press; 1999. p. 617-783.

5. McCord JM, Fridovich I. Superoxide dismutase. An enzymic function for erythrocuprein (hemocuprein). J Biol Chem. 1969;244:6049-55.

6. Martin ME, Byers BR, Olson MOJ, Salin ML, Arceneaux JEL, Tolbert C. Streptococcus mutans superoxide dismutase that is active with either manganese or iron as a cofactor. J Biol Chem. 1986;261:93671-6.

7. Mandelli F, Franco Cairo JPL, Citadini APS, Buchli F, Alvarez TM, Oliveira RJ, et al. The characterization of a thermostable and cambialistic superoxide dismutase from Thermus filiformis. Lett Appl Microbiol. 2013;57:40-6.

8. Dussurget O, Stewart G, Neyrolles O, Pescher P, Young D, Marchal G. Role of Mycobacterium tuberculosis copper-zinc superoxide dismutase. Infect Immun. 2001;69:529-33.

9. Youn HD, Kim EJ, Roe JH, Hah YC, Kang SO. A novel nickel-containing superoxide dismutase from Streptomyces spp. Biochem J. 1996;318:889-96.

10. Eickhoff J, Potts E, Valtos J, Niederhoffer EC. Heavy metal effects on Proteus mirabilis superoxide dismutase production. FEMS Microbiol Lett. 1995;132:271-6.

11. Ferianc $P$, Farewell $A$, Nyström $T$. The cadmium-stress stimulon of Escherichia coli K-12. Microbiology. 1998;144:1045-50.

12. Bébien M, Chauvin J-P, Adriano J-M, Grosse S, Verméglio A. Effect of selenite on growth and protein synthesis in the phototrophic bacterium Rhodobacter sphaeroides. Appl Environ Microbiol. 2001;67:4440-7.

13. Borsetti F, Tremaroli V, Michelacci F, Borghese R, Winterstein C, Daldal F, et al. Tellurite effects on Rhodobacter capsulatus cell viability and superoxide dismutase activity under oxidative stress conditions. Res Microbiol. 2005;156:807-13.

14. Ramirez-Díaz MI, Díaz-Pérez C, Vargas E, Riveros-Rosas H, Campos-García J, Cervantes C. Mechanisms of bacterial resistance to chromium compounds. Biometals. 2008;21:321-32.

15. Ackerley DF, Barak Y, Lynch SV, Curtin J, Matin A. Effect of chromate stress on Escherichia coli K-12. J Bacteriol. 2006;188:3371-81.

16. Hu P, Brodie EL, Suzuki Y, McAdams HH, Andersen GL. Whole-genome transcriptional analysis of heavy metal stresses in Caulobacter crescentus. J Bacteriol. 2005;187:8437-49.

17. Branco R, Chung AP, Johnston T, Gurel V, Morais PV, Zhitkovich A. The chromateinducible chrBACF operon from the transposable element TnOtChr confers resistance to chromium(VI) and superoxide. J Bacteriol. 2008;190:6996-7003.

18. Branco R, Morais PV. Identification and characterization of the transcriptional regulator $\mathrm{ChrB}$ in the chromate resistance determinant of Ochrobactrum tritici 5bvl1. PLoS One. 2013;8:11.

19. Roux M, Covés J. The iron-containing superoxide dismutase of Ralstonia metallidurans CH34. FEMS Microbiol Lett. 2002;210:129-33.

20. Beauchamp C, Fridovich I. Superoxide dismutase: improved assays and an assay applicable to acrylamide gels. Anal Biochem. 1971;44:276-87.

21. Tan BH, Leow TC, Foo HL, Rahim RA. Molecular characterization of a recombinant manganese superoxide dismutase from Lactococcus lactis M4. BioMed Res Int. 2014;2014:469298.

22. de Lorenzo V, Timmis K. Analysis and construction of stable phenotypes in gram-negative bacteria with Tn5- and Tn10-derived minitransposons. Methods Enzymol. 1994;235:386-405.

23. Echave P, Tamarit J, Cabiscol E, Ros J. Novel antioxidant role of alcohol dehydrogenase E from Escherichia coli. J Biol Chem. 2003;278:30193-8.

24. Yu NY, Wagner JR, Laird MR, Melli G, Rey S, Lo R, et al. PSORTb 3.0: Improved protein subcellular localization prediction with refined localization subcategories and predictive capabilities for all prokaryotes. Bioinformatics. 2010;26:1608-15.

25. Beyer WF, Fridovich I. Assaying for superoxide dismutase activity: some large consequences of minor changes in conditions. Anal Biochem. 1987;161:559-66.

26. Fridovich I. Superoxide dismutases. Adv Enzymol Relat Areas Mol Biol. 1986;58:61-97.

27. Bostwick DG, Alexander EE, Singh R, Shan A, Qian J, Santella RM, et al. Antioxidant enzyme expression and reactive oxygen species damage in prostatic intraepithelial neoplasia and cancer. Cancer. 2000;89:123-34.

28. Melov S, Ravenscroft J, Malik S, Gill MS, Walker DW, Clayton PE, et al. Extension of life-span with superoxide dismutase/catalase mimetics. Science. 2000;289:1567-9.
29. Liu JG, Yin MM, Zhu H, Lu JR, Cui ZF. Purification and characterization of a hyperthermostable Mn-superoxide dismutase from Thermus thermophilus HB27. Extremophiles. 2011;15:221-6.

30. Song NN, Zheng Y, SJ E, Li DC. Cloning, expression, and characterization of thermostable manganese superoxide dismutase from Thermoascus aurantiacus var. levisporus. J Microbiol. 2009;47:123-30.

31. Zhu Y, Wang G, Ni H, Xiao A, Cai H. Cloning and characterization of a new manganese superoxide dismutase from deep-sea thermophile Geobacillus sp. EPT3. World J Microbiol Biotechnol. 2014;30:1347-57.

32. Lim JH, Yu YG, Choi IG, Ryu JR, Ahn BY, Kim SH, et al. Cloning and expression of superoxide dismutase from Aquifex pyrophilus, a hyperthermophilic bacterium. FEBS Lett. 1997;406:142-6.

33. Yu J, Yu X, Liu J. A thermostable manganese-containing superoxide dismutase from pathogen Chlamydia pneumonia. FEBS Lett. 2004;562:22-6.

34. Thompson DK, Chourey K, Wickham GS, Thieman SB, VerBerkmoes NC, Zhang $B$, et al. Proteomics reveals a core molecular response of Pseudomonas putida F1 to acute chromate challenge. BMC Genomics. 2010;11:311.

35. Liu KJ, Shi X. In vivo reduction of chromium $(\mathrm{VI})$ and its related free radical generation. Mol Cell Biochem. 2001;222:41-7.

36. Joutey NT, Sayel H, Bahafid W, El Ghachtouli N. Mechanisms of hexavalent chromium resistance and removal by microorganisms. In: Whitacre DM, editor. Reviews of Environmental Contamination and Toxicology. Switzerland: Springer; 2015. p. 45-69.

37. Brown SD, Thompson MR, VerBerkmoes NC, Chourey K, Shah M, Zhou J, et al. Molecular dynamics of the Shewanella oneidensis response to chromate stress. Mol Cell Proteomics. 2006:5:1054-71.

38. Saenkham P, Eiamphungporn W, Farrand SK, Vattanaviboon P, Mongkolsuk S. Multiple superoxide dismutases in Agrobacterium tumefaciens: functional analysis, gene regulation, and influence on tumorigenesis. J Bacteriol. 2007:189:8807-17.

\section{Submit your next manuscript to BioMed Central and we will help you at every step:}

- We accept pre-submission inquiries

- Our selector tool helps you to find the most relevant journal

- We provide round the clock customer support

- Convenient online submission

- Thorough peer review

- Inclusion in PubMed and all major indexing services

- Maximum visibility for your research

Submit your manuscript at www.biomedcentral.com/submit 